\title{
KOMIK STRIP DAN FENOMENA CLICKBAIT
}

\author{
Godham Eko Saputro ${ }^{1 *}$, Toto Haryadi² \\ 1,2Program Studi Desain Komunikasi Visual, Universitas Dian Nuswantoro \\ Diterima: 30 Januari 2019 / Disetujui: 4 Maret 2019
}

\begin{abstract}
The ease on accessing of information have two sides: good and bad impacts. Information which is very much and updated in seconds cause website and social media are used to spread unreliable news, one of them is clickbait. Clickbait increases massively and make people receive information which is not match with given titles. This caused by news and content creators motive in getting much advantage especially in form of money. This problem need to be countered use medium which is also used by them, namely social media. This research use qualitative method to explore clickbait phenomenon through methods of observation, literature study, and researcher's direct experience when accessing clickbait news. Researchers use framing analysis method to breakdown some facts about clickbait to create statement as basic of design process. Design Thinking method is choosen to design strip comics as media to present information about clickbait. The content of strip comics is packed with humorous approach so that audiences easer to understand the messages. Through this strip comics, researchers hope that comic artists, graphic designers, or lecturers of Visual Communicatoin Design can involve theirselves in countering clickbait news so that people can obtain reliable and useful information.
\end{abstract}

Keywords: clickbait, design thinking, comic, strip

\begin{abstract}
ABSTRAK
Kemudahan dalam mengakses informasi berdampak positif sekaligus negatif bagi masyarakat. Informasi yang sangat banyak dan update dalam hitungan detik menyebabkan website dan sosial media menjadi tempat menyebarkan berita-berita yang tidak kredibel, salah satunya yaitu clickbait. Clickbait semakin masif dan membuat masyarakat menerima informasi yang tidak sesuai dengan judul yang ditampilkan. Hal ini muncul karena adanya keuntungan yang bisa diperoleh penyebar konten clickbait. Masalah ini perlu diberantas dengan cara melawan clickbait menggunakan media yang juga digunakan oleh penyebar clickbait, yaitu sosial media. Penelitian ini menggunakan metode kualitatif untuk mendalami fenomena clickbait melalui proses observasi, studi literatur, serta pengalaman langsung peneliti saat mengakses berita clickbait. Analisis permasalahan menggunakan framing dengan memaparkan beberapa realita terpilih untuk menemukan statement sebagai dasar perancangan karya. Metode Design Thinking dipilih untuk mengembangkan komik strip sebagai media untuk memberikan informasi seputar fenomena clickbait. Komik strip dirancang menggunakan cerita humor agar mudah dipahami oleh target audiens. Melalui komik ini pula peneliti berharap agar praktisi maupun akademisi bidang desain komunikasi visual turut serta membantu memberantas clickbait agar masyarakat memperoleh informasi yang kredibel dan bermanfaat.
\end{abstract}

Kata Kunci: clickbait, design thinking, komik, strip

\section{PENDAHULUAN}

Membaca sebuah artikel di media online atau timeline Facebook, tidak jarang dijumpai judul artikel yang menggunakan awalan hiperbolis seperti "HEBOH", "BIKIN SEDIH", "GREGET", $\begin{array}{llr}\text { "TERKUAK!", } & \text { "NOMOR } & \text { TIGA } \\ \text { MENGEJUTKAN", } & \text { "VIRAL" } & \text { atau }\end{array}$ "ASTAGA!". Dijumpai pula judul artikel yang ambigu atau multitafsir karena ketika membuka artikel tersebut, informasi yang didapatkan kurang atau bahkan tidak sesuai dengan judul. Pada intinya judul tersebut

*email: godham.eko@gmail.com 
berusaha mengajak pengunjung untuk mengklik artikelnya supaya mendapatkan banyak penghasilan darinya. Hal ini merupakan imbas dari peralihan media cetak menuju media online memunculkan berbagai aliran jurnalisme baru yang lazim dengan nama clickbait.

Clickbait atau umpan klik menurut sengedan.com adalah adalah sebuah istilah untuk menggambarkan konten web yang hanya bertujuan mendapatkan viewer atau pembaca, tanpa memperdulikan kualitas dan akurasi konten yang disajikan, dengan bergantung pada judul yang sensasional dan memprovokasi atau cuplikan gambar yang mendorong orang untuk membaca atau melihatnya. Sedangkan menurut kamus digital marketing seperti yang dikutip dalam digitalentrepreneur.id, clickbait adalah istilah yang (biasanya) merendahkan pada konten web (biasanya pada judul konten), yang tujuan utamanya adalah membuat pengguna meng-klik tautan untuk membuka laman web tertentu.

Beberapa contoh clickbait yang penulis temui di internet antara lain: 1). Sebuah media terkenal yang memuat judul tentang video eksklusif 12 Menit percakapan terakhir pilot sebelum tragedi terjatuhnya pesawat sebuah maskapai penerbangan, yang akhirnya dihujat para netizen karena terindikasi clickbait. 2). Orang biasa yang tertimpa musibah dan beritanya menjadi viral hanya memiliki nama yang sama dengan seorang tokoh terkenal. 3).Thumbnail atau preview gambar yang mewakili isi video pada Youtube yang sengaja dibuat buram, berlebihan, atau berupa penampakan.

Clickbait, meskipun disebut sebagai salah satu strategi marketing sebuah media online, tetapi memiliki dampak buruk kepada pengunjung yang merasa terjebak atas ketidakakuratan informasi yang didapat, serta waktu yang terbuang sia-sia. Kekecewaan pengunjung bahkan dapat menurunkan brand atau kredibilitas sang pembuat konten. Gerakan melawan clickbait pun muncul sebagai jawaban atas kegelisahan para netizen. Akun twitter bernama@ClickUnbait memiliki misi memerangi clickbait serta mengapresiasi media yang membuat konten penting dan menarik dengan cara yang kreatif, yaitu memakai tagar \#JudulYangBaik dan \#RekomendaKlik. Tetapi hal tersebut dirasa kurang cukup. vice.com menuliskan bahwa berdasarkan data statistik UNESCO, tingkat literasi bangsa Indonesia berada di peringkat 60 dari total 61 negara. Hal ini sangat mengkhawatirkan karena bilamana orang malas membaca isi artikel dan hanya membaca judul secara sekilas saja, maka sangat berpotensi terjadi mispersepsi dan berujung pada hoax atau berita palsu yang berakibat pada perpecahan dalam masyarakat.

Usulan atas permasalahan tersebut adalah menciptakan terobosan baru dalam membangun kesadaran masyarakat untuk menangkal clickbait. Ilmu Desain Komunikasi visual terbukti efektif melakukan perancangan kampanye sosial yang kreatif dan inovatif, salah satu luarannya menggunakan komik strip untuk menangkal clickbait. Pemanfaatan komik sebagai media perancangan kampanye sosial yang efektif dan efisien telah beberapa kali dilakukan oleh Saputro dan Haryadi (2018) dengan menelurkan komik strip bertema anti hoax. Hal ini yang menjadi landasan peneliti untuk memanfaatkan komik strip lagi sebagai motor gerakan melawan clickbait.

\section{TINJAUAN TEORI}

Merujuk sejarah, clickbait sudah ada sejak 100 tahun yang lalu. Situs Iluminasi.com menyebutkan peristiwa meledaknya kapal perang Amerika, USS Maine di pelabuhan Kuba, dimana awalnya adalah pemberitaan yang biasa saja, mendadak gempar setelah Koran yang 
dimiliki Pullitzer dan Rudolph memuat judul provokatif dan bermuara clickbait. Inti dari judul tersebut bernada provokatif yang menyebutkan bahwa ledakan diakibatkan oleh serangan Spanyol, dimana hal ini dilakukan semata-mata dengan tujuan menarik pembaca untuk membeli Koran mereka. Berita koran tersebut akhirnya menjadi pemicu perang antara Spanyol dan Amerika, walau faktanya ledakan berasal dari dalam kapal sendiri dan bukan dari serangan luar.

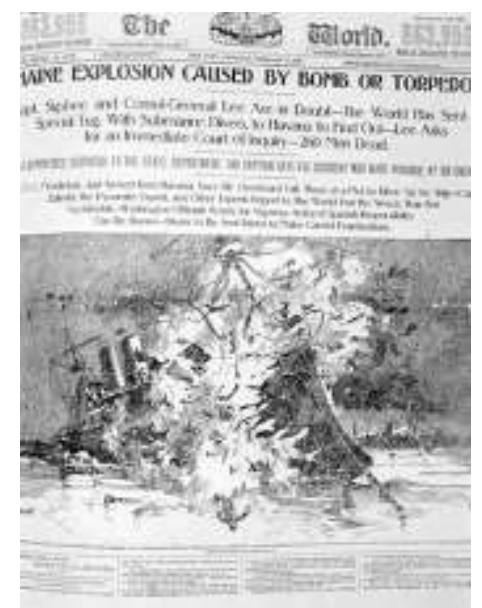

\section{Gambar 1. Contoh berita clickbait}

Sumber: iluminasi.com

Pada medio 2018 Perusahaan media asal Inggris, We Are Social dan Hootsuite merilis data yang menyebutkan bahwa dalam sehari, rata-rata orang Indonesia mengakses sosial media selama tiga jam 23 menit. Sosial media yang digemari di Indonesia dari tahun ke tahun masih belum banyak berubah, masih didominasi oleh WhatsApp, Facebook, dan Instagram. Sedangkan para pengguna aktif sosial media di Indonesia mencapai 130 juta dengan penetrasi 49 persen dari total populasi orang Indonesia sebanyak 265,4 juta jiwa.

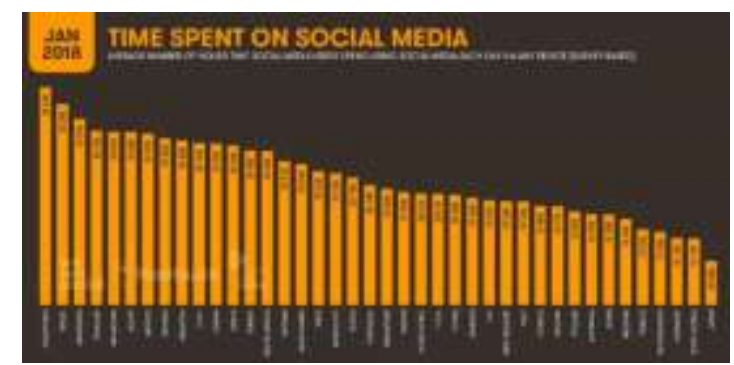

\section{Gambar 2. Presentasi orang Indonesia ketika mengakses sosial media Sumber: tekno.kompas.com}

Untuk mengaksesnya, para pengguna menggunakan smartphone atau tablet dimana kini hampir semua orang memilikinya. Karena biasanya dalam sosial media terdapat tombol berbagi atau share, maka banyak ditemukan para pengguna yang berbagi sebuah berita di timeline-nya atau grup khusus. Banyaknya berita yang dapat di share membuat produsen konten berita berlomba-lomba mengadaptasi dari model cetak ke model online sehingga akses penyebaran berita menjadi lebih efektif dan efisien. Para produsen konten berita juga diuntungkan karena akan meningkatkan traffic atau kunjungan ke situs berita online mereka. Seperti peristiwa perang SpanyolAmerika diatas, strategi clickbait banyak diadopdi para produsen konten berita supaya beritanya menarik perhatian pengguna bahkan menjadi viral.

Sedangkan kepopuleran komik strip berbanding lurus seiring dengan merambahnya smartphone dan internet ke semua kalangan. Komik strip yang banyak ditemukan di sosial media terdiri atas satu hingga empat panel dalam sekali terbit, yang digambar dengan penggayaan sederhana dan kartunal, serta lebih berorientasi pada fenomena yang sedang marak (saputro dan haryadi, 2017). Banyak komik strip bertema sosial bahkan satire yang di-share oleh netizen karena merasa muak dengan keadaan sosial, politik, bahkan hoax yang merajai timeline sosial media.

\section{METODE PENELITIAN}

\section{Metode Penelitian}

Penelitian ini menggunakan pendekatan kualitatif, yang fokus terhadap pendalaman gejala, fakta, dan realita, yaitu tentang fenomena maraknya clickbait dalam kehidupan sehari-hari. Data seputar clickbait 
yang menjadi topik dalam penelitian ini diperoleh dengan cara observasi, studi literatur melalui website dan sosial media yang menjadi sarang maraknya clickbait, serta melibatkan pengalaman langsung dalam menyusuri konten-konten clickbait.

\section{Metode Analisis}

Metode analisis yang digunakan dalam penelitian ini yaitu framing, yaitu menyajikan peristiwa dengan menonjolkan aspek tertentu agar khalayak bisa mengingatnya. Fakta seputar clickbait akan disajikan dalam tabel framing yang berisi fakta, ideal, penyebab, serta statement. Hasil analisis framing akan dijadikan acuan dalam menghasilkan perancangan komik strip yang mengangkat fenomena clickbait.

\section{Metode Perancangan Komik Strip}

Perancangan komik strip menggunakan metode Design Thinking, yaitu metode praktis yang mengaktualisasi ide dan konsep untuk merangsang cara berpikir yang menginspirasi munculnya inovasi. Metode ini memiliki tahapan emphatize, define, ideate, prototype, dan test. Langkah tersebut diarahkan untuk proses perancangan komik strip yang mengangkat fenomena clickbait.

\section{HASIL DAN PEMBAHASAN}

\section{Analisis framing fenomena Click bait}

Berdasarkan hasil pengamatan, studi literatur, serta pengalaman langsung dari peneliti, fenomena click bait ditampilkan dalam tabel framing berikut ini:

\section{Tabel 1. Framing Clickbait}

\section{Framing pertama}

a. Fakta : Clickbait menyebar sangat masif.

b. Ideal : Clickbait bisa dikendalikan melalui kontrol Pemerintah. c. Penyebab: Pergerakan informasi yang sangat cepat di internet.

d. Statement: Waspadai maraknya clickbait di sekitar kita.

2. Framing kedua

a. Fakta : Banyak masyarakat terkecoh berita clickbait.

b. Ideal : Masyarakat mampu mengidentifikasi dan menghindari clickbait.

c. Penyebab: Literasi yang masih rendah.

d. Statement: Perluas wawasan dan pengalaman Anda untuk mengenali clickbait.

\section{Framing ketiga}

a. Fakta : Pembuat dan penyebar link clickbait semakin merajalela

b. Ideal : Jumlah dan pergerakan pelaku bisa diberantas.

c. Penyebab: Mengejar keuntungan hasil dari aktivitas tersebut.

d. Statement: Pikirkan kembali dampak clickbait bagi orang lain.

Dari tiga framing di atas, statement yang dipilih yaitu "perluas wawasan dan pengalaman Anda untuk mengenali clickbait". Statement ini dipilih sebagai landasan konsep komik strip bahwa untuk mengurangi dampak buruk akibat clickbait, masyarakat harus mengenali clickbait, tidak menggubrisnya, serta tidak melakukan share kepada pihak lain.

Perancangan komik strip melalui metode Design Thinking

Perancangan komik strip menggunakan tahapan Design Thinking, yang dimulai dari empathize, define, ideate, prototype, dan test. Breakdown tiap tahapan Design Thinking bisa dilihat pada tabel berikut ini:

Tabel 2. Breakdown Design Thinking 
1. Empathize: Memahami karakter target audiens.

Audiens yang dituju yaitu masyarakat pengguna aktif sosial media, suka membaca berita, cenderung mudah menshare informasi, serta kurang hati-hati.

2. Define: membuat list kebutuhan target audiens.

Audiens membutuhkan sumber informasi yang bisa menambah pengetahuan tentang clickbait, yang disampaikan secara singkat, padat, jelas, tidak menggurui, dan mudah dicerna, serta bisa diakses dimana pun dan kapan pun.

3. Ideate: mengambarkan solusi yang dibutuhkan

Untuk mengedukasi target audiens tentang fenomena clickbait, peneliti memilih komik strip 1 hingga 4 panel. Topik yang akan diangkat yaitu tentang contoh berita clickbait, tips menghadapi clickbait, clickbait dalam bentuk video, serta contoh kejadian nyata yang dijadikan clickbait.

4. Prototype: membuat komik strip sesuai dengan topik yang ditentukan.

Tahapan merancang komik dimulai dengan penentuan skenario atau storytelling yang didapat dari hasil riset dan brainstorming. Skenario akan dibuat versi storyboard-nya dalam bentuk sketsa kasar pensil, dilanjutkan dengan penintaan (inking) dan diubah menjadi format digital (scanning). Langkah terakhir adalah melakukan pewarnaan dan pengaturan layout dengan software grafis, serta output-nya adalah file .jpeg yang siap diunggah di berbagai sosial media.

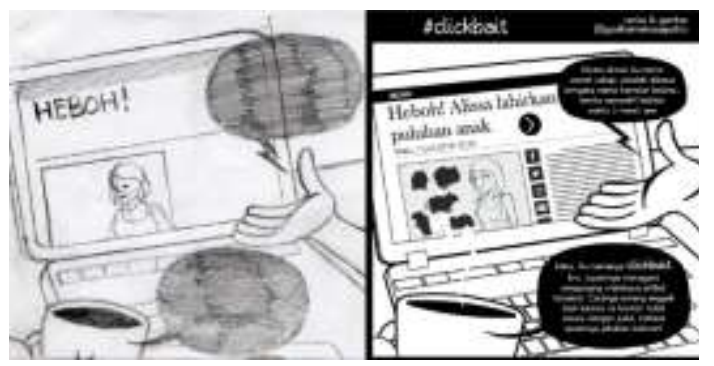

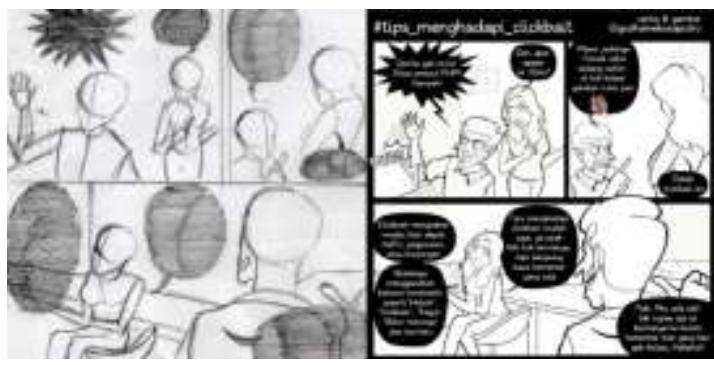
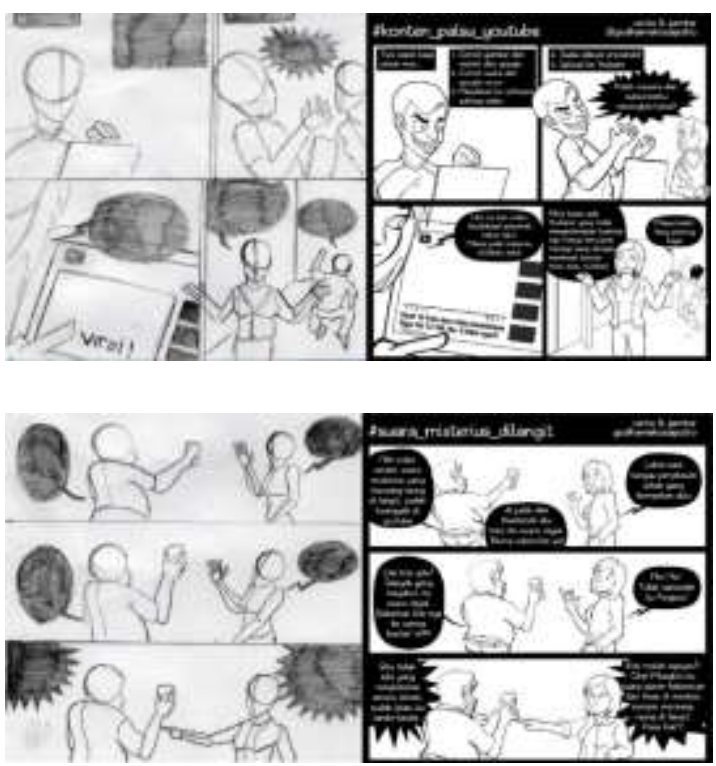

Gambar 3: Sketsa, inking, dan tata letak.

Sumber: Saputro \& Haryadi (2018)

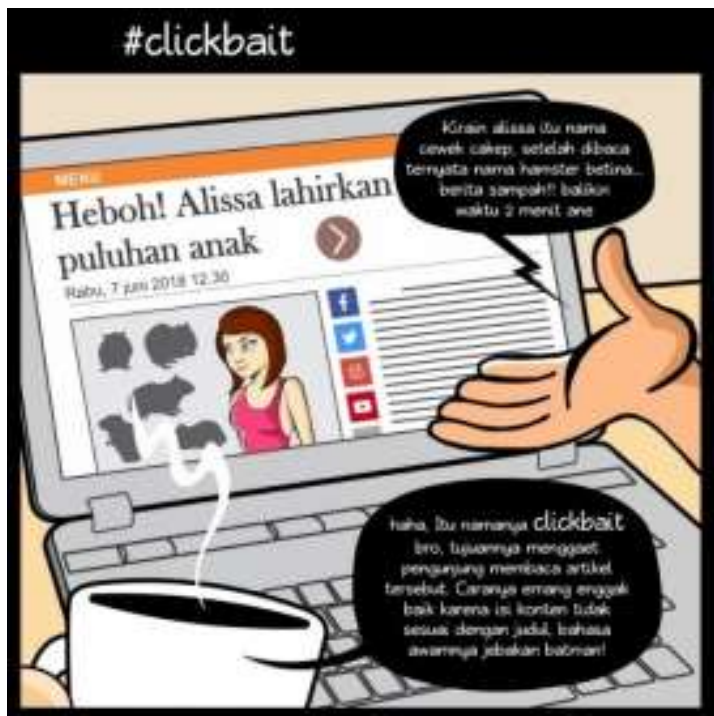

Gambar 4: Komik ke-1 berita clickbait

Sumber: Saputro \& Haryadi (2018) 


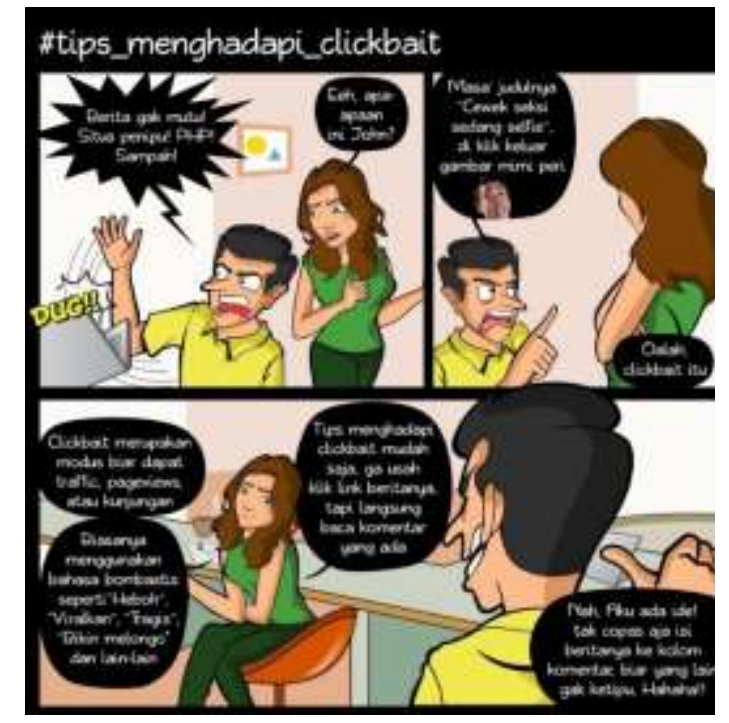

Gambar 5: Komik ke-2

Tips menghadapi clickbait

Sumber: Saputro \& Haryadi (2018)

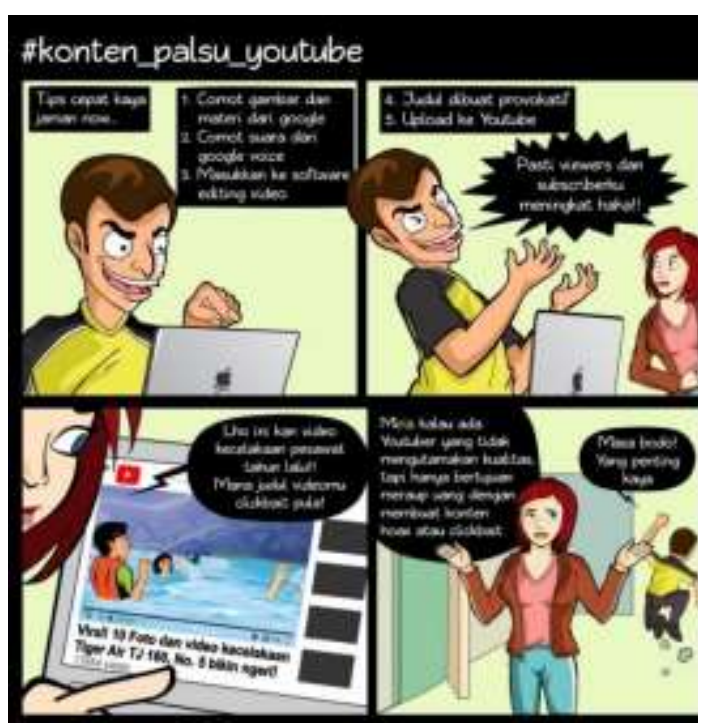

Gambar 6: Komik ke-3

Clickbait dalam bentuk video

Sumber: Saputro \& Haryadi (2018)

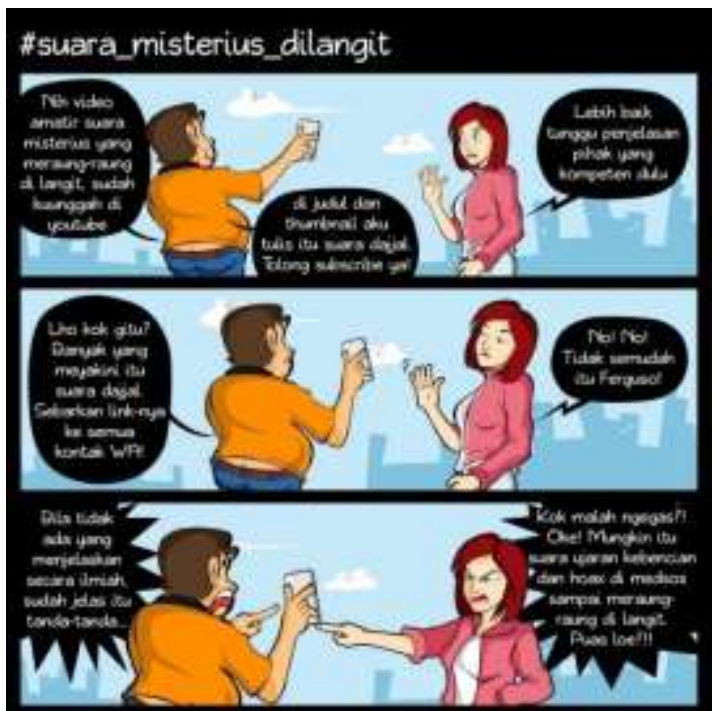

Gambar 6: Komik ke-4

Contoh kejadian nyata yang dijadikan clickbait

Sumber: Saputro \& Haryadi (2018)

5. Test: menguji komik strip dengan diupload di sosial media (facebook)

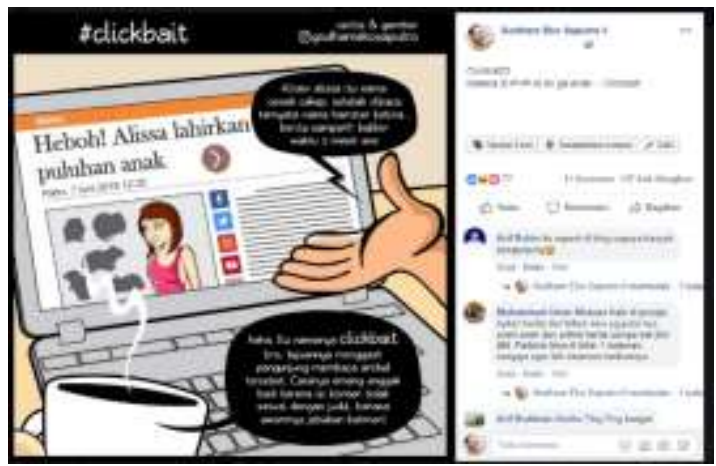

Gambar 7: Upload komik ke-1, 137 kali dibagikan, 77 like, dan 11 komentar

Sumber: screenshot facebook 


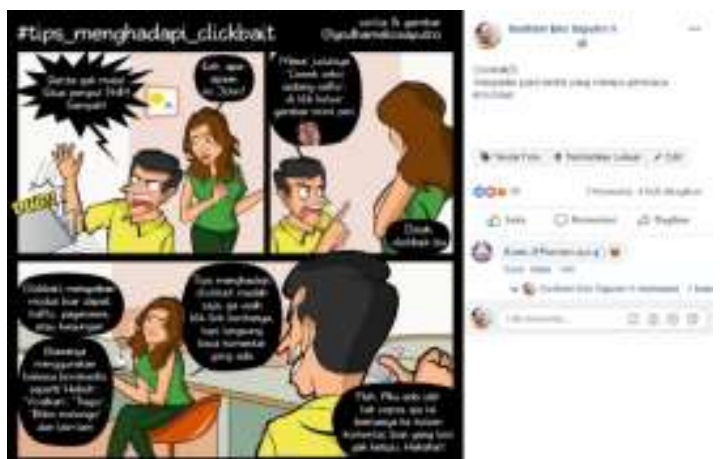

Gambar 7: Upload komik ke-2, 4 kali dibagikan, 38 like, dan 2 komentar Sumber: screenshot facebook

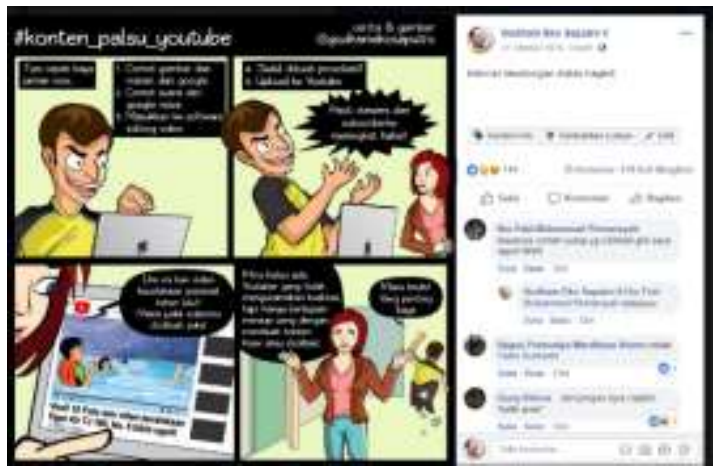

Gambar 9: Upload komik ke-3, 419 kali dibagikan, 144 like, dan 35 komentar.

Sumber: screenshot facebook

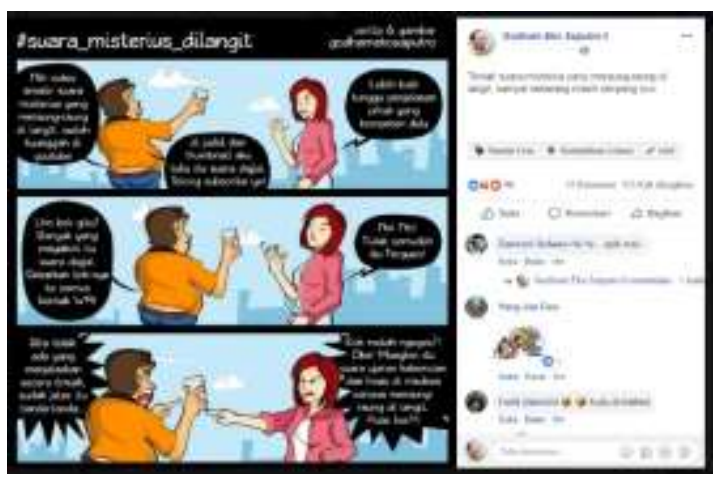

Gambar 10: Upload komik 4, 113 kali dibagikan, 96 like, dan 11 komentar. Sumber: screenshot facebook

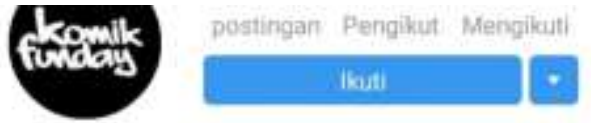

komikfunday

Comic by @godhamekosaputro

Kindly contact me via wa +62856-4254-1985 LHAAT TERJEMAHAN

Dilkiti olith retnokariwahyuni, godhamekosaputro febryfadhlorrochman +8 tinimilya

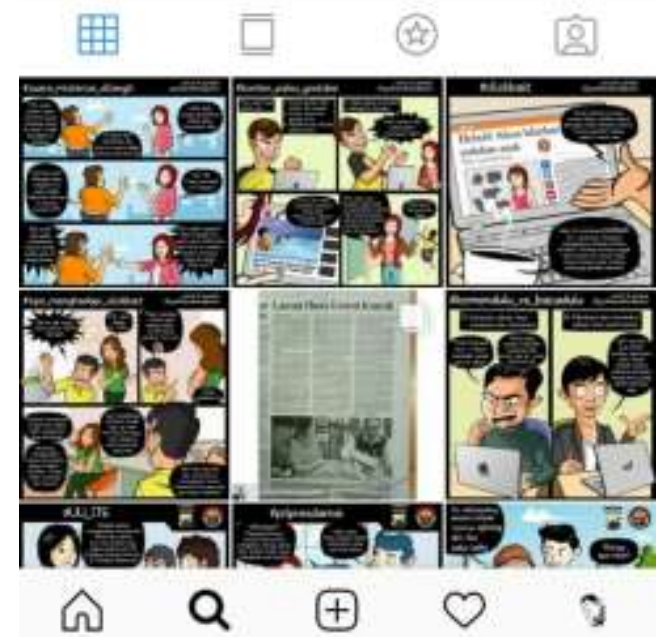

Gambar 11: Fanspage komik di instagram

Sumber: screenshot instagram

\section{SIMPULAN}

Berdasarkan hasil perancangan komik strip di atas, untuk melawan fenomena clickbait dibutuhkan media yang tepat untuk target audiens. Media yang tepat di sini yaitu komik strip 1 hingga 4 panel yang ringan dibaca, bisa diakses dimana pun dan kapan pun, tidak menggurui, serta disampaikan dengan pendekatan humor agar lebih mudah diterima. Komik strip yang telah dirancang juga diunggah di sosial media sesuai dengan habitual target audiens yang tidak lepas dari smartphone. Hal ini juga disebabkan untuk melawan sesuatu yang beredar di internet, maka harus menggunakan saluran internet juga. Dengan mengambil topik yang dekat dengan seharihari, diharapkan target audiens memperoleh informasi yang mudah dicerna tentang fenomena clickbait meliputi: contoh berita 
clcikbait, cara melawan clickbait, apa saja yang bisa dijadikan clickbait, serta contoh kejadian nyata yang berpotensi dijadikan clickbait. Dengan pengetahuan tersebut diharapkan semakin berhati-hati dalam menyikapi berita yang beredar melalui internet dalam media website maupun sosial media.

\section{DAFTAR PUSTAKA}

\section{Buku}

Eriyanto, 2002. Analisis Framing: Konstruksi, Ideologi, dan Politik Media. Jogjakarta: LKiS Group

Raco, J.R., 2018. Metode Penelitian Kualitatif: Jenis, Kharakteristik, dan Keunggulannya. Jakarta: GRASINDO

Ramdhan, H.E., 2015. Startupreneur: Menjadi Entrepreneur Startup. Jakarta: PenebarPlus

\section{Internet}

Deddy, Samuel. (2017). Rumus Bikin Judul yang Click Bait Tapi Tidak Menipu Pembaca. Artikel laman: https://digitalentrepreneur.id/rumus -judul-click-bait/. (Diakses 29 desember 2018).

Fahmi, Ichiro. (2017). Apa itu Clickbait Pengertian Penerapan dan Bahayanya. Artikel laman: https://www.sengedan.com/2017/04 lapa-itu-pengertian-clickbait.html. (Diakses 27 desember 2018).

Mohamad, Mira. (2018). Sejarah 'clickbait' yang mencetuskan perang antara Sepanyol dan Amerika. Artikel laman: https://iluminasi.com/bm/inilahasal-usul-clickbait-yang-telahmencetuskan-peperangan-antarasepanyol-danamerika.html?fbclid=IwAR20ZixA
LLONvwVeLNFEOtWGHNSLUL _c0kGxgW-

mwYc79nSeQyBccP6X2zc.

(Diakses 4 januari 2019).

Pertiwi, Wahyunanda Kusuma . (2018). Riset Ungkap Pola Pemakaian Medsos Orang Indonesia. Artikel laman: https://tekno.kompas.com/read/201 8/03/01/10340027/riset-ungkappola-pemakaian-medsos-orangindonesia. (Diakses 6 januari 2019).

Wargadiredja, Arzia Tivany. (2017). ClickUnbait Memerangi Judul Artikel Bombastis di Jagat Media Daring Kita. Artikel laman: https://www.vice.com/id_id/article/ a378mz/clickunbait-memerangijudul-artikel-bombastis-di-jagatmedia-daring-kita. (Diakses 